\section{Isolation of a polymorphic DNA sequence (LL101) from the short arm of chromosome 17 [D17S251]}

\author{
P.I.Patel ${ }^{*}$, D.H.Ledbetter, S.Frances, \\ B.Franco, M.R.Wallace ${ }^{2}$, F.S.Collins ${ }^{2}$ and \\ J.R.Lupski' \\ Institute for Molecular Genetics and ${ }^{1}$ Department \\ of Pediatrics, Baylor College of Medicine, \\ Houston, TX 77030 and ${ }^{2}$ Division of Medical \\ Genetics, University of Michigan Medical Center, \\ Ann Arbor, MI 48109, USA
}

Source/Description: LL101 is a recombinant bacteriophage (vector: $\lambda \mathrm{Ch} 3 \mathrm{~A} \Delta l a c \mathrm{XN}$ ) containing a $9.0 \mathrm{~kb}$ Not I fragment. This clone was isolated from a NotI linking library constructed from the chromosome 17 fraction of a flow-sort of human chromosomes (1).

Polymorphism: PvuII identifies a two-allele polymorphism with fragments of $13 \mathrm{~kb}(\mathrm{P} 1)$ and $8.6 \mathrm{~kb}(\mathrm{P} 2)$ in a Caucasian population. Three additional alleles were observed in U.S. blacks (P3 = $15 \mathrm{~kb} ; \mathrm{P} 4=8 \mathrm{~kb} ; \mathrm{P5}=6 \mathrm{~kb}$ ). Invariant fragments of $2.0 \mathrm{~kb}$, $1.6 \mathrm{~kb}, 1.1 \mathrm{~kb}, 1.0 \mathrm{~kb}, 0.64 \mathrm{~kb}$ and $0.5 \mathrm{~kb}$ are also observed.

$\begin{array}{llllll}\text { Allele Frequency: } & \text { P1 } & \text { P2 } & \text { P3 } & \text { P4 } & \text { P5 } \\ \text { U.S. Blacks }(\mathrm{N}=6) & 0.49 & 0.16 & 0.08 & 0.08 & 0.16\end{array}$

Not Polymorphic For: MspI, PstI, RsaI.

Chromosomal Localization: LL101 is localized to $17 \mathrm{p} 13.100-17 \mathrm{p} 13.105$ using a previously published chromosome 17 somatic cell hybrid panel $(2,3)$. This localization is based on the presence of $\mathrm{LL101}$ in hybrid $\mathrm{JW}-4$ retaining a $\operatorname{del}(17)(\mathrm{p} 13.105)(2)$ and its absence in hybrid HO-11 retaining a $\operatorname{del}(17)(\mathrm{p} 13.100)(3)$.

Mendelian Inheritance: Co-dominant segregation of the two-allele polymorphism (P1, P2) has been observed in one three generation family where 34 individuals were typed (4).

Probe Availability: Contact P.I.Patel.

Other Comments: Preassociation with human placental DNA is required prior to hybridization at normal stringency $\left(65^{\circ} \mathrm{C}\right.$, $1 \mathrm{MNa}^{+}$).

References: 1. Wallace,M.R. et al. (1989) Nucl. Acids Res. 17, 1665-1677. 2. van Tuinen,P. et al. (1987) Genomics 1, 374-381. 3. van Tuinen,P. et al. (1988) Am. J. Hum. Genet. 43, 587-596. 4. Patel,P.I. et al. (1990) Am. J. Hum. Genet. 46.

* To whom correspondence should be addressed

\section{Mspl and Pvull polymorphisms in the $\mathrm{Na}, \mathrm{K}$ - ATPase $\beta$ subunit gene ATP1B1}

\author{
M.M.Shull, D.G.Pugh, L.K.Lane and \\ J.B.Lingrel * \\ Department of Molecular Genetics, Biochemistry \\ and Microbiology, University of Cincinnati \\ College of Medicine, 231 Bethesda Avenue, \\ Cincinnati, OH 45267-0524, USA
}

Source/Description: ATP1B HH1.2 is a $1.2 \mathrm{~kb}$ HindIII fragment from the $3^{\prime}$ portion of the human $\mathrm{Na}, \mathrm{K}-\mathrm{ATPase} \beta$ subunit gene, ATP1B1 (1).

Polymorphism: MspI identifies a two allele polymorphism (M1: $6.7 \mathrm{~kb}, \mathrm{M} 2: 5.3 \mathrm{~kb}$ ). PvuII also detects a two-allele polymorphism (P1: $5.1 \mathrm{~kb}, \mathrm{P} 2: 4.7 \mathrm{~kb})$.

Frequency: Estimated from 15 unrelated Caucasians.

MspI M1: 0.5

PvuII P1: 0.63

M2: 0.5

P2: 0.37

Not Polymorphic For: BamHI, BglII, HindIII, KpnI, PstI, SstI, XbaI.

Chromosome Location: ATP1B1 has been assigned to chromosome 1q by somatic cell hybrid analysis (2).

Mendelian Inheritance: Codominant segregation of the Msp I RFLP was observed in one two-generation family (5 individuals). Codominant segregation of the PvuII RFLP was observed in a two-generation (8 individuals) and a three-generation (12 individuals) family. Linkage disequilibrium exists between the two polymorphisms. Although insufficient chromosomes were investigated to compute the level of disequilibrium accurately, it is evident that added information will be gained by using both polymorphisms.

Probe Availability: Contact Dr J.B.Lingrel.

References: 1. Lane,L.K. et al. (1989) Genomics 5, 445-453. 2. Yang-Feng,T.L. et al. (1988) Genomics 2, 128-138.

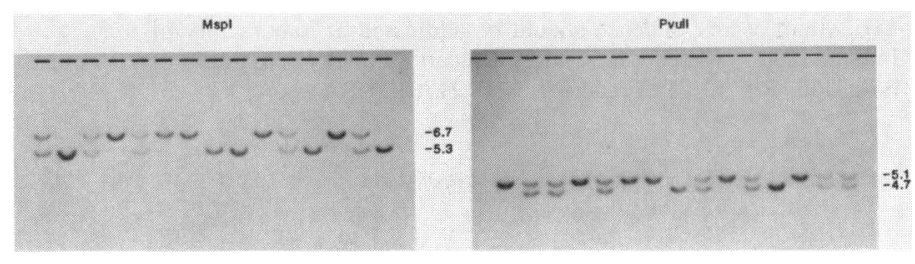

* To whom correspondence should be addressed 